\title{
An Examination of the Experiences of Black Football Athletes
}

\author{
Jeff Porter \\ University of Michigan
}

\begin{abstract}
The purpose of this study was to understand the experiences of Black college athletes that played football and graduated from a Division I Power 5 institution. It is well documented that Black football players graduate from Power 5 institutions lower rates than any other student or athlete group, due to a variety of obstacles they face on campus. Despite these obstacles, there are athletes in this group who do graduate from their institution and successfully transition into professional careers. The research conducted for this article is adapted from a dissertation that explores the campus environment that Black college football players must navigate. This article focuses on the impact the social support network has, helping these athletes maneuver through their organizational environment and prepare for life after athletics. Understanding the possible influences of a support network can be a critical strategy for the survival of this group of athletes.
\end{abstract}

Keywords: Black college athletes; football; academic success; college transition

The foundation of Division I athletic departments largely depends on the success of their football programs. This dependence creates a tremendous amount pressure to win games and further establishes the contradictory pressures placed on college football players. These contradictory pressures include attempting to excel athletically while trying to fulfill the necessary academic requirements required to maintain eligibility and progress towards degree completion (Beamon, 2008; Coakley, 2009; Gatmen, 2011; NCAA, 2015).

Harper, Williams, and Blackman (2012) found that although Black males comprise $6 \%$ or less of the entire student population at institutions in the 'Power 5 ' conferences, Black males are significantly overrepresented in football and comprise the majority of the athletes on the team (Beamon, 2008; Harper, 2006; Reynolds, Fisher, \& Cavil, 2012). Black athletes are recruited by universities because of their athletic abilities and it is argued that minimal attention is paid to the academic preparation of these athletes (Beamon, 2008; Donnor, 2005; Sanders \& Hildenbrand, 2010; Simiyu, 2012). Once on campus, Black men must contend with a host of other psychosocial factors that impact their overall college experience and academic goals, especially at predominantly White institutions. Some of these factors include racial discrimination, campus isolation, prejudiced faculty, alienation, increased pressure to athlet- 
ically perform, and being ill-prepared for college academic requirements (Beamon, 2008; Bimper, Harrison, \& Clark, 2012; Comeaux, 2008; Comeaux, 2012; Comeaux \& Harrison, 2007; Donnor, 2005; Gragg \& Flowers, 2014; Melendez, 2008).

Unlike their White counterparts, Black football players not only have to navigate conflicting academic and athletic pressures, but must also manage the hostile environment that is pervasive on the campuses of predominantly White institutions. Bimper et al. (2012) notes that Black athletes must cope with the racial and 'dumb jock' stereotypes, which are forms of racialized mircoaggressions that "convey racially charged messages to people of color" (Comeaux, 2012, p. 190). The impact of these mircoaggressions has real life effects for the Black athletes. Not only can these stereotypical beliefs lead to an internalization of such beliefs which narrow self-concepts and behavior choices, the stereotypes can lead Black athletes to "self-stereotype as dumb jock and thus develop a perilously heightened sense of athletic identity" (Bimper et al., 2012, p. 110). Simiyu (2012) also notes that Black athletes received lower grades, suspected or accused of academic misconduct, and given a difficult time when requesting accommodations due to athletic travel schedules. Unfortunately, the racial stereotypes and mircoaggressions from the campus community contribute to the reported feelings of isolation and alienation from Black athletes. They view the campus as a hostile environment and they subsequently withdraw from the campus community, making it challenging to fully engage in the active learning process (Bimper et al., 2012; Coakley, 2009; Comeaux, 2012; Simiyu, 2012).

Despite the series of obstacles and structural constraints they must overcome (i.e., campus racism, isolation, faculty stereotypes, poor academic preparation, and excessive emphasis on winning by internal and external constituents), there are Black college athletes that fulfill the necessary academic requirements to graduate from their institutions (Gragg \& Flowers, 2014).

\section{Purpose of Study}

The purpose of this study was to understand the experiences of Black college athletes that played football and graduated from a Division I Power 5 institution (e.g. ACC, Big Ten, Big 12, Pac-12, \& SEC conferences) described as "State University" throughout this study. Much of the current research on Black college athletes has painted a bleak picture of this population by focusing on the lack of academic persistence, disturbing graduation rates, lower GPAs, and below average pre-college academic experiences (Benson, 2000; Harper, 2009; Sellers, 1992), which originates from a deficit perspective. This deficit perspective implies that the lack of academic persistence (i.e., progress towards and completion of bachelor's degree) of this population is primarily the fault of the college athlete (Benson, 2000).

Many Black male college athletes have demonstrated resiliency and subsequently matriculated to graduation, which becomes a point worthy of further exploration. Resilience can best be described as "patterns of positive adaption in the context of significant risk or adversity" (Masten \& Powell, 2003, p. 4). Resiliency requires two judgments: (1) a person is "doing good and (2) that there is now or has been signifi- 
cant risk or adversity to or something to overcome" (Masten \& Powell, 2003).

There are two clear aspects of the present study that differentiate it from previous research. First, although similar studies undertaken have examined "successful" Black male college athletes (Bimper et al., 2012; Cooper \& Cooper, 2015; Martin, Harrison, \& Bukstein, 2010), the term "success" is vague and often leaves room for interpretation. Academic success for one college athlete can mean something vastly different for another athlete. To minimize the variety of interpretation from previous research, graduation was the focal point of this research, which is a clear difference between the current study and previous research. Second, Bimper et al. (2012), Cooper \& Cooper (2015), and Martin et al. (2010) all examine the experiences of current Black college athletes across several sports. The current study was unique in that it is centrally focused on Black football players that have graduated from their institution. This information provides a reflective examination of their experiences now that they have matriculated beyond the college setting and into their professional life.

To build on the previous literature surrounding this population, to better understand their experiences on the college campus, and what contributed to their graduation within the institutional environment, the central research question that guided this study was: How did Black male football student-athletes manage to graduate while being part of a Division 1 team at a research-intensive institution?

Benson (2000) states, "future research should continue to investigate student athletes' experiences and perspectives so as to add to the body of descriptive literature that may help redesign educational practices" (p. 242), which becomes the final purpose for conducting this study. Although research has been about Black male college students have been conducted, their graduation rates are still some of the lowest rates of any student group on college campuses (see Table 1). When discussing Black football college athletes, researcher often discuss systemic challenges and issues they encounter. However, what makes this study unique is that an organizational framework was applied to the system of intercollegiate athletics, which helps to situate the experiences of these Black football athletes in the proper organizational context.

\section{Literature Review}

Before examining the academic performance of college athletes, it is necessary to examine the larger societal context, systemic inequalities, and disadvantages that permeate through every aspect of life for Black Americans. Black Americans 25 years old and over "have higher unemployment rates $(4.3 \%$ and $8.9 \%$ for White and Black males respectively) and longer durations of unemployment than their White counterparts (an average of 12.1 weeks compared to 8.8 weeks)" (Harris, 2010, p. 245). Jones and Schmitt (2014) note that a significant reason for this level of unemployment among Black Americans is due to racial discrimination in the labor markets. Quillian, Pager, Hexel, and Midtbøen (2017) found that on average White applicants received $35 \%$ more callbacks than an equally qualified Black applicant and 
overall found little reduction in hiring discrimination against Black Americans. Pager, Western, and Bonikowski (2009) found that not only were Black men less likely to receive a call back than an equally qualified White counterpart, Black applicants were placed at the bottom in the racial hierarchy as the employers favored White men. More recently, Reeves (2014) found evidence that supervising lawyers found Black lawyers to be substandard in their writing skills in comparison to their White counterparts, when given the same legal brief. This example identifies racial bias operating in plain sight. Racial disparities are also felt when considering promotions. Smith (2005) found that Black men must work longer periods of time after leaving school than their White counterparts to earn similar promotions. Furthermore, Harris (2010) points out that credentials of Black employees receive more intense scrutiny than their White counterparts when in contention for promotions.

The socioeconomic status of Black Americans also has a direct effect on the education their children receive. Aud, Fox, and Kewal-Ramani (2010) found that Black children are more likely to attend high poverty schools than their Asian and White counterparts. Approximately 50\% of Black children will attend low-income high schools (as compared to $11 \%$ of White students) that have drop-out rates that average $50 \%$ or greater and $60 \%$ of students that live below the poverty line (Hughes, 2013). School districts that contain a disproportionate number of minorities receive less funding per students compared to school districts that have less minority students (Berliner, 2013; Green, 2008; Palmer, Davis, Moore, \& Hilton, 2010), which is one critical way in which the systemic imbalances take form. The fact is that political power of a neighborhood and property taxes, which are a key source of funding for schools, have established systems of schooling that resemble apartheid like systems. Berliner (2013) further notes that $48 \%$ of high poverty schools receive less funding in their district compared to low-poverty schools and that schools that exceed a $75 \%$ poverty rates score significantly lower than their wealthier counterparts.

Another area in educational systems in which systemic racial imbalances is on full display is the interaction between the teachers and students. Research suggests that it is common for Black students to experience racial discrimination due to the negative stereotypes of being dangerous and threatening projected onto them (Hope, Skoog, \& Jagers, 2015). Black youth are consistently viewed as suspicious and subjected to constant surveillance, which have very real consequences for these students. Hope et al. (2015) found that Black students faced verbal abuse, psychological and physical mistreatment, were subjected to receiving lower grades by teachers, and harsher disciplinary punishments as compared to their White counterparts (Warikoo, Sinclair, Fei1, \& Jacoby-Senghor, 2016). Hope et al. (2015) further establishes that "the experience of teacher discrimination has a negative effect on academic performance, while peer discrimination contributes to psychological adjustment problems" (p. 85).

Azzam (2008) found that high - achieving Black students may be exposed to less rigorous curriculums, attend schools with fewer resources, and have teachers that expect less out of them academically compared to their White counterparts. Warikoo et al. (2016) indicated that compared to White students, Black students were referred 
less to gifted-and-talented programs and more to special-needs testing by teachers who used less positive language when speaking to Black students (Palmer et al., 2010; Whiting, 2009). Not only are Black male disproportionately concentrated in special-needs or special education programs, they are more likely to be classified as having intellectual disabilities or labeled as having learning disabilites (Palmer et al., 2010). These structural inequalities are key contributors to the significant underrepresentation of Black students in gifted education programs and are stifled by a deeply ingrained bias of equating White and whiteness with superiority (Ford, 2014).

Unfortunately, teachers (and counselors) play a vital role in these structural inequalities experienced by Black men. It is commonplace for teachers and counselors to impose low or negative expectations on Black males, which can have damaging effects on their expectations for academic success in the future and deter them from pursuing college or advanced degrees (Hayes, Cunningham, \& Courseault, 2006; Palmer et al., 2010). Harris (2010) found that "by age 17 the average Black student is four years behind the average White student; Black $12^{\text {th }}$ graders score lower than White $8^{\text {th }}$ graders in United States (U.S.) history and geography" (p. 247). This information demonstrates that Black males are at a "disadvantage beginning in their earliest schooling experiences" (p. 126) and even though teachers and counselors have low expectations of Black males, these same students have "high academic and career aspirations" (p. 126). Regardless of the perceptions imposed upon these students, they still have a passion to learn and achieve (Hayes et al., 2006).

Considering the systemic imbalances that occur in elementary and secondary schooling, it should come as no surprise that these trends continue throughout college. Harper (2006) found that nationwide, $67.6 \%$ of Black men who start college do not graduate within six years, which is the lowest completion rate of any group and between both sexes (Owens, Lacey, Rawls, Holbert-Quince, 2010). Owens et al. (2010) also notes that Black students have been found to be less academically prepared for college level academia, have less information about the college process, and typically Black students face a hostile environment upon their entry into higher education. In addition to encountering a hostile environment and not being academically prepared for college, Palmer et al. (2010) says that minority students are more likely to encounter problems with completing their degree due to the large share of financial aid that goes unmet. Low-income students have the "greatest disparity between their aid packages and cost of attendance" (p. 113). All this works together to inhibit Black students from matriculating to graduation.

Any conversation about the current status of Black men would be incomplete without exploring the effects of the criminal justice system. Recent attention has centered on the school-to-prison pipeline which can be best be described as a national trend in which children are funneled out of public school and into the criminal justice system (Dancy, 2014). The school-to-prison pipeline disproportionately affects Black males. Palmer et al. (2010) notes that Black males are disciplined, face more expulsions, and suspended for longer periods of time as compared to their White counterparts. According to the U.S. Department of Education Office for Civil Rights, Black students represent $27 \%$ of students referred to law enforcement and $31 \%$ of 
students subjected to school-related arrest (2014).

The school-to-prison pipeline effectively becomes a series of discipline techniques, that includes out of school suspension, designed to alienate Black males from the learning environment by navigating them away from the classroom and toward the criminal justice system (Darensbourg, Perez, \& Blake, 2010). Statistics about the criminal justice system further underscores that point. A 2013 report from The Sentencing Project found that although Black Americans comprise approximately $12 \%$ of the United States population, in 2011 Black Americans constituted 30\% of people arrested for a property offense and $38 \%$ of people arrested for a violent offense. In addition, Black males are six times more likely to be incarcerated than White males and if current trends continue, one in three Black men can expect to go to prison in their lifetime. This report also notes that the common adjectives associated with Black Americans are "dangerous," "aggressive," "violent," and "criminal" (The Sentencing Project, 2013, p. 4). These characterizations and "subconscious racial associations influence the way officers perform their jobs" (The Sentencing Project, 2013 , p. 4). Butler (2012) states that prosecutors "coerce guilty pleas by threatening defendants with vastly disproportionate punishment if they go to trial" (p. 2184). According to Carson (2014), "non-Hispanic Blacks (37\%) comprised the largest portion of male inmates under state or federal jurisdiction in 2013" (p. 1). These factors combined, create significant challenges that Black Americans must overcome daily in order to survive in the United States.

\section{Academic preparation of Black college athletes}

Sellers' (1992) foundational work on Black college athletes, which is often referred to in current literature, finds that in general Black athletes tend to matriculate from lower socioeconomic backgrounds and are less academically prepared for college academia compared to their White counterparts (Bimper et al., 2012; Owens, Lacey, Rawls, \& Holbert-Quince, 2010). Like their non-athlete counterparts, Black college athletes typically come from environments that have inferior academic resources to adequately prepare the prospective college athlete for college academia (Comeaux, 2008; Cooper, 2012; Palmer et al., 2010). This information is critical because the previous research on academic success of college athletes has found that a key predictor of academic success is largely dependent on their high school GPAs and students from lower socioeconomic backgrounds tend to have lower GPAs compared to those from higher socioeconomic backgrounds (Astin, 1993; Chen, Mason, Middleton, Salazar, 2013; Simiyu, 2012; Sellers, 1992). Therefore, if the foundation of college athlete research suggests that high school GPA is the single most consistent and important factor for predicting academic success in college, it should then come as no surprise that Black football athletes have some of the overall lowest GPAs and subsequent graduation rates of any student group on campus.

There are two schools of thought that explain why this population of students has not performed well academically and why they are continuously graduating at lower rates compared to all other groups on campus. Benson (2000) and Palmer et al. (2010) note that one school of thought is that poor academic performance 
is primarily the fault of the students in question because they are deficient in some aspect and as Ogbu (2004) suggests, that academic achievement can be perceived as "acting White" (p. 2). This perspective is commonly known as the deficit model or deficit perspective, which asserts that minority groups do not perform as well as their White counterparts in school and in life because their cultural environment is perceived to be dysfunctional and lacking important characteristics (Salkind, 2008). This perspective further suggests that Black students do not aspire to or strive to get good grades because it can be perceived by members of that community as acting White and thus, abandoning their community and their culture (Ogbu, 2004; Palmer et al., 2010).

The counter narrative however, suggests that the poor academic performances of Black college athletes is not attributed to their lack of ability or actions but is the result of difficulty trying to navigate the different technical functions of the athletic and academic environments (Benson, 2000; Simiyu, 2012). Unfortunately, contending with the organizational culture present at PWI's, Black college athletes also reported being singled out and treated differently as compared to their counterparts (Cooper \& Hawkins, 2014; Bimper et al., 2012). Black college athletes often experience little control over their academic planning, being placed into classes that can potentially have adverse effects towards overall degree completion (Bimper et al., 2012; Singer, 2005), and are advised to focus less on class and academic related activities and spend more time dedicated to sport - related activities.

\section{On campus experiences}

Black college athletes, especially those in the revenue - producing sports, often experience double standards, value differences, separation, stigma from faculty and classmates, and unwritten rules placed on Black college athletes. White college athlete counterparts also did not experience the same racial stigmas and often received more favorable treatment from the campus compared to the Black college athletes (Beamon, 2014; Melendez, 2008). In addition, during their time on campus, Black football athletes reported feeling unfairly judged by classmates, White teammates, and coaches (Bimper et al. 2012; Harrison, 2001; Melendez, 2008).

Simons et al. (2007) found that faculty held negative perceptions of Black college athletes and would make comments supporting these stereotypes and attitudes towards the Black athletes (Beamon, 2014; Bimper et al., 2012; Comeaux, 2008). Comeaux (2008) found that there is a stigma associated with Black college athletes as academically inferior not only by faculty, but by the campus community (Simiyu, 2012). Simons et al., (2007) states that, "there is an understandable resentment of athletes who are admitted with lower academic qualifications by non-athlete students who worked so hard to gain admission to the university" (p. 267). Sanders and Hildenbrand (2010) found that in such cases, Black college athletes face a double stigma (i.e., being Black and an athlete), which portrays them as "inferior academically by the campus community" (Comeaux, 2008, p. 8). Specifically, the 'dumb jock' stereotype is routinely associated with college athletes but resonates heavily with Black athletes in particular (Bimper et al., 2012; Sailes, 1993). Although an older 
study, Sailes (1993) provided foundational work about the 'dumb jock' stereotype and found that "white and males felt more strongly that the African American athlete was not as academically prepared to be in college" (p. 95). The premise of this stereotype is that Black males are academically inferior but athletically superior to their White counterparts (Cooper, 2012; Martin, Harrison, Stone, \& Lawrence, 2010; Sailes, 2010).

In the same manner, preconceived notions, stereotypes, and stigmas about Black college athletes propagate the plantation system in terms of the demographic imagery on college campuses (Hawkins, 2010). An article in the Chronicle of Higher Education reports that Black college athletes often feel that professors think they are there simply to play a sport without any intention to learn, are not taken seriously by professors, receive lack of interest from the professors, and are the subjects of nasty or subtle racial comments made by professors (Perlmutter, 2003). Therefore, the campus community treats these Black athletes, not as equal members but as commodities to be used for the advancement of the university's national profile.

Negative perceptions from campus and faculty members about college athletes is the cause for the creation of a discriminatory campus climate and one that is perceived as hostile by the college athletes (Comeaux, 2012). Comeaux (2012) further states that these college athletes routinely experience microaggressions and microassaults, which are the results of stereotypes and assumptions made about the intellectual ability of the college athletes. One of the underlying components when discussing the hostile campus environment has to do with race. Black college athletes not only have to manage the stereotypes of being an athlete but also being Black, which compounds their experience (Beamon, 2014). The racism that Black football players experience not only comes from the campus and faculty members but also from fans, which only exacerbates the already hostile environment (Beamon, 2014).

Cooper (2012) found that Black college athletes also contend with a lack of leadership opportunities within their teams and being treated differently than their White counterparts. Singer (2008) found that Black college athletes are often shut out from certain positions that are perceived as leadership positions (e.g., quarterback). Along with the lack of leadership positions, Singer (2008) also found that Black college athletes experienced differential treatment between themselves and their White counterparts from coaches.

Each college athlete must, at some level, battle their conflicting roles of being a college student and a college athlete. Cooper and Cooper (2015) use role theory to discuss this phenomenon whereas Potuto and O'Hanlon (2007) tend to focus on identity. Either way, the fact remains that Black college athletes are more influenced by their sport participation (Potuto \& O'Hanlon, 2007) and feel more pressure to "develop an athletic identity and an academic identity" (Bimper et al., 2012). Cooper and Cooper (2015) found that athlete stereotypes, athletic schedules and the athletic business contributed to the athletes' role conflict. Potuto and O'Hanlon (2007) found that a larger portion of Black athletes "seem more likely to focus on and be influenced by athletics" (p. 961). Prospective Black college athletes are more susceptible to the allure of an athletic scholarship and subsequently confront their conflicting 
role identity because the scholarship provides them with a means to attend a university they may not have otherwise been able to afford (Duderstadt, 2000).

\section{Impact of commercialism on college athletics}

Davis' (1994) work is often cited and lays a critical foundation regarding the history of Black athletes in intercollegiate athletics. Cooper (2012) says that during the early 1900 s, the few Black athletes that did compete for White institutions were funneled into sports such as track and field and to a lesser extent football, since these sports were viewed as "not involving the type of intimate physical contact required by basketball and swimming" (Davis, 1994, p. 632). During and post-World War II, college athletic programs had to search for talented athletes from previously untapped sources to maintain the competitiveness of their teams (Davis, 1994; McCormick \& McCormick, 2012; Spivey, 1983). The war, combined with the increased commercialization and professionalization of collegiate athletics, drastically increased the number of Black student-athletes attending PWIs (McCormick \& McCormick, 2012). This increased commercialization of football in particular provided Black athletes with greater access to these White institutions that previously prohibited their access (McCormick \& McCormick, 2012). As a result of the increased commercialization of college athletics, athletic departments were now faced with more pressure to win and to "field winning teams" (Davis, 1994, p. 634). Davis (1994) notes that after World War II, Black athletes were now being funneled into the revenue-producing sports (p. 635). This passion to win amongst the institutions, fans, and students created an atmosphere that put aside blatant discriminatory practices to reap the economic benefits associated with the commercialism of college athletics (McCormick \& McCormick, 2012). The expanding commercialization of college athletics only seems to further establish the role conflict for the college athletics. The commercialization of college football places added pressure on the coach to field winning teams and sends conflicting messages to the players about where the academic priorities lie in the context of their sport participation (Simiyu, 2012). Comeaux (2008) discussed the current impact of the increased commercialization of college athletics by stating that "college athletics have become more commercialized with a greater urgency to produce winning seasons and secure corporate sponsors at the expense of the student-athletes' academic future" (p. 1). This is one of the key systemic factors that has had a devastating effect on the academic pursuits of Black college athletes and only reinforces the plantation system perception.

\section{Overrepresentation}

Although a minority in the United States, Black men are overrepresented among football players in the 'Power 5' conferences. According to data from the NCAA (2015), across the Power Five conferences Black college athletes comprised the majority $(48 \%)$ of the football teams (see Table $5 \& 6$ ) during the last two academic years (2013/14 and 2014/15), while Black males (during the same time period) comprise no more than six percent of the entire undergraduate population (Harper, 2012; Sellers, 2000; Simiyu, 2012). Because Black college athletes are needed to maintain 
a high level of team performance, the idea that they are doing all the work while the other predominately White college athletes are reaping all the rewards, strengthens the plantation system perception (Beamon, 2008). It also suggests that Black males are not good enough to attend predominantly White institutions without being put to work on the field.

Harper et al. (2012) found that across four cohorts of college athletes (i.e., students who entered college in the same academic year), Black college athletes graduated at a rate of $50.2 \%$ within six years, compared to $66.9 \%$ of overall college athletes, $72.8 \%$ of all undergraduate students and $55.5 \%$ of Black male undergraduate non-athletes. Table 1 breaks down the major college athlete groups and sports for the 2008 cohort and compares both the GSR (created by the NCAA) and the FGR. Regardless of the statistical measured used, Black college athletes that play football graduate at some of the lowest rates of any student group on college campuses.

\section{Theoretical Framework}

There are two conceptual frameworks that helped to guide the present study. The first was Comeaux and Harrison's (2011) work that builds upon previous literature focused on cognitive and non-cognitive variables predicting academic success. The contribution of Comeaux and Harrison (2011) is that they approached the examination of college athlete academic success from a qualitative tradition, calling attention to the necessity to explore the environment of the college athletes in order to understand how they navigate college towards academic success.

\section{Table 1}

Comparing Graduation Success Rates vs. Federal Graduation Rates (2008 Cohort)

\begin{tabular}{l|c|c}
\multicolumn{1}{c|}{ Student-Athlete Group } & $\begin{array}{c}\text { 2008 (Cohort) } \\
\text { GSR (\%) }\end{array}$ & $\begin{array}{c}\text { 2008 (Cohort) } \\
\text { FGR (\%) }\end{array}$ \\
\hline Men's Basketball & 77 & 47 \\
\hline White Men's Basketball & 90 & 57 \\
\hline African American Men's Basketball & 72 & 41 \\
\hline Football (FBS) & 75 & 61 \\
\hline White Football (FBS) & 84 & 71 \\
\hline African American Football (FBS) & 69 & 56 \\
\hline Women's Basketball & 89 & 62 \\
\hline White Women's Basketball & 95 & 68 \\
\hline African American Women's Basketball & 84 & 58
\end{tabular}

National Collegiate Athletic Association. (2014). Trends in graduation success rates and federal graduation rates at NCAA Division I institutions. NCAA. 
Comeaux and Harrison's (2011) model "presumes that a student-athletes' academic success will be based primarily on a set of individual characteristics and dispositions, with effects from the social and academic systems within which the student-athlete operates" (p. 237). Their model is segmented into several parts that illustrate how the various aspects fit together into a cumulative model. The first aspect of this model begins with pre-college variables that include family background (i.e., parental/guardian education, parental/guardian support), individual attributes (i.e., race, gender, academic motivation), and educational experiences (i.e., high school). Student-athletes' initial commitments make up the next stage of the model. Student-athletes' commitments include: goal, sport, and institutional. The next stage examines the academic and social environments of the university. The ability of the student-athletes to assimilate into the various environments is an important factor in their collective experiences. The social environment includes faculty and peer interactions, along with sport and coaches' demands. The academic environment includes grade performance and intellectual development, whereas grade performance is more explicit and the intellectual development is an intrinsic reward. The model concludes with an examination of student-athlete commitments (e.g., goal, sport, and institutional) leading to academic success.

Consistently being incorporated into research, Comeaux and Harrison's (2011) model offers guidance into helping understand and improve academic outcomes for college athletes (Comeaux, 2013; Cooper; 2016; Cooper \& Dougherty, 2015; Grandy, Lough, \& Miller, 2016). This model supposes that as college athletes become more integrated into the social and academic environments, they have a better chance for academic success (Comeaux, 2013; Comeaux, Bachman, Burton, \& Aliyeva, 2017; Comeaux \& Harrison, 2011; Cooper; 2016; Cooper \& Dougherty, 2015; Grandy et al., 2016). However, a critique of this model is that it combines the college athlete experience into just the academic and social systems but does not adequately call out sport participation. According to the Comeaux and Harrison's (2011) model, sport participation becomes part of the social system. The "sport participation" (early on in the model) refers to the time athlete dedicated to their sport prior to entering the college environment. In addition, Comeaux and Harrison's (2011) model does not segment or illustrate the potential growth and development that athletes experience from their freshman to senior year. As the model currently stands, freshman to senior year are reduced to academic and social systems.

Notwithstanding the criticisms, Comeaux and Harrison's (2011) model helps to inform this study in two critical areas. First, the model calls out the pre-college experiences and factors that contribute to academic performance (Cooper, 2016). These experiences cannot be overlooked because they are the foundation which athletes enter into the college environment with, especially for Black athletes. Second, Comeaux and Harrison's model considers the importance of the integration into the social and academic systems as a pivotal component which directly impacts the academic success of the college athletes. Black athletes often feel socially isolated and alienated on the college campus (Carter-Francique, Hart, \& Steward, 2013), which can make it challenging to fully engage with the campus community. Therefore, this 
model helps underscore the importance of campus (e.g. academic \& social) engagement on academic success.

To better understand the system of intercollegiate athletics (within the higher education system), the second conceptual framework that helped to inform this study is Muwonge's (2012) model of organizational rationality that expanded upon the work of Parson (1960), Thompson (1967), and Scott (2003) (See figure 1).

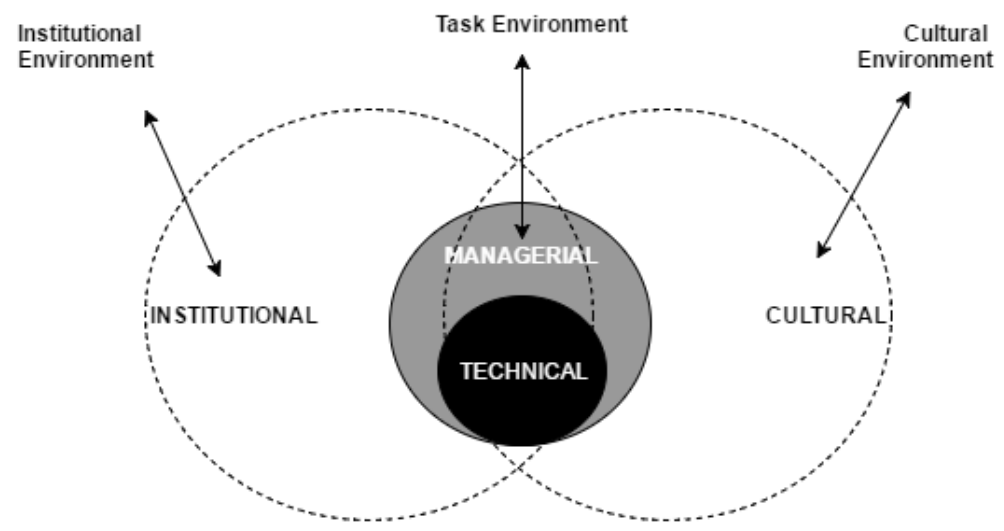

Figure 1. Levels of organizational activities.

The technical level deals with the core function, or production, of the organization, essentially changing inputs into outputs (Thompson, 1967, 2003). The managerial level of the organization is responsible for designing procedures, procuring resources, and allocating personnel to perform different functions (Scott, 2003; Thompson, 1967, 2003). The institutional level is concerned with the organization and its larger environment, or social system, which determines its meaning or legitimacy and the boundaries of the organization (Scott, 2003; Thompson, 1967, 2003). Lastly, the cultural environment is concerned with constructing meaning or establishing the organization's right to exist. Organizations transmit culture to its members while engaging in specific tasks to ensure its survival. As a result, the people within the organization create norms, values, rules, and symbols to demonstrate how things are done that help people survive within the organization (Morgan, 1997). Table 2 illustrates how this organizational model applies to college athletic departments and to the academic side present at State University. By examining both the academic and athletic organizational context in which the Black college athlete must contend, the challenges they face become even more apparent due to the conflicting primary functions of the academic and athletic entities.

The limitation with this framework is that it is only useful to in helping to understand the organizational context, which the college athlete experience is situated. Because of this limitation, it cannot stand-alone to examine the actual lived experiences of the college athletes. Using this model, however frames the intercollegiate athletics environment in such a way to better understand the college athletes' perspectives in proper context of the environment in which it is situated. 
Table 2

Organizational Environment Summary (Athletics \& Academics)

\begin{tabular}{|c|c|c|}
\hline & Academics & Athletics (Football) \\
\hline Technical Core & Produce Graduate Students & Produce Football Games \\
\hline $\begin{array}{l}\text { Task/Resource } \\
\text { Environment }\end{array}$ & Grants & $\begin{array}{c}\text { Spectator Tickets \& } \\
\text { Conference Media } \\
\text { Contracts }\end{array}$ \\
\hline $\begin{array}{c}\text { Task/Resource } \\
\text { Environment } \\
\text { (Students) }\end{array}$ & Predominantly White & Predominantly Black \\
\hline $\begin{array}{c}\text { Cultural } \\
\text { Environment } \\
\text { (Meaning } \\
\text { Construction) }\end{array}$ & $\begin{array}{l}57 \% \text { of students come } \\
\text { from in-state; average } \\
\text { family income greater than } \\
\$ 100 \mathrm{~K}\end{array}$ & $\begin{array}{l}\text { Larger percentage of } \\
\text { student-athletes are from } \\
\text { mid-west; much more } \\
\text { variability in home state } \\
\text { \& SES }\end{array}$ \\
\hline $\begin{array}{l}\text { Institutional } \\
\text { Environment }\end{array}$ & $\begin{array}{l}\text { Federal Agencies; State } \\
\text { Agencies; Higher Learning } \\
\text { Commission (HLC) }\end{array}$ & $\begin{array}{l}\text { NCAA; Power } 5 \\
\text { Conference }\end{array}$ \\
\hline Managerial Activities & $\begin{array}{c}\text { Housed within the } \\
\text { university }\end{array}$ & $\begin{array}{l}\text { Housed within the Athletic } \\
\text { Department }\end{array}$ \\
\hline
\end{tabular}

\section{Methods}

A qualitative case study approach was utilized for this study, as described by Merriam (2009). The Power 5 Conference institution that serves as the unit of analysis (referred to from here on as State University or SU to protect the identity of the institution) has a student population of over 30,000 students (both graduate and undergraduate). State University has been considered one of the premier research universities in the world for several decades and has a nationally recognized college football program that ranks as one of the best all-time. The Black student population when these former college athletes attended was just below 10\% and according to the participants, the campus overall was not overly welcoming but not overly hostile. Data was collected from individual interviews (with 5 former student-athletes and 7 faculty and staff members), and document collection (e.g., alumni profiles, media guides, \& student-athlete questionnaires).

\section{Participant Criteria}

Purposeful sampling was utilized in selecting qualified participants for this study because it used a predetermined set of criteria for inclusion in this study (Patton, 2002). 
Therefore, the target population for this study were former Black college athletes that received an athletic scholarship, participated in football between 2003 and 2010, and graduated from State University. This study primarily focused on Black male student-athletes who received athletic scholarships to participate in football because these athletes are recruited by coaches because of their athletic ability and potential to immediately contribute to the team (Beamon, 2008).

\section{Participant Selection}

The researcher began the study by scheduling interviews with the associate athletic director and the football academic counselor. These interviews informed the researcher of other faculty and staff members that met the selection criteria. Two faculty members, one (football) position coach, one former academic advisor, and one assistant athletic director agreed to be interviewed.

Eight athlete interviews were completed, transcribed, replayed for accuracy, and sent back to the participants to verify their comments, each transcription was reviewed in significant detail. By the time the eighth interview occurred, no additional information was being uncovered. The researcher continued interviewing participants when the saturation point was close to being achieved as Patton (2002) recommends to sample until the point of redundancy. Of the eight athletes that were initially interviewed, five were selected as part of this study because these five participants provided what Patton (2002) describes as information - rich cases in which a thorough analysis can be performed. Table 3 illustrates a brief overview of the academic profile and current career placement of the participants.

Table 3

Former College Athlete Major, Current Career \& Letter winner Status

\begin{tabular}{|c|c|c|c|c|}
\hline & GPA & Major & Current Career & $\begin{array}{l}\text { Letter- } \\
\text { winner } \\
\text { Status }\end{array}$ \\
\hline FSA 1 & $2.4-2.9$ & General Studies & $\begin{array}{l}\text { Affordable Real } \\
\text { Estate Developer }\end{array}$ & $4 x$ \\
\hline FSA 2 & $2.4-2.9$ & Sport Management & $\begin{array}{l}\text { College Football } \\
\text { Coach }\end{array}$ & $4 x$ \\
\hline FSA 3 & $2.4-2.9$ & Sociology & $\begin{array}{c}\text { HS Associate AD/ } \\
\text { Head Football } \\
\text { Coach }\end{array}$ & $4 x$ \\
\hline FSA 4 & $2.4-2.9$ & Communications & $\begin{array}{l}\text { College Football } \\
\text { Coach }\end{array}$ & $4 x$ \\
\hline FSA 5 & $3.0-3.4$ & General Studies & NFL Free Agent & $4 x$ \\
\hline
\end{tabular}




\section{Data Analysis}

Constant comparison was that analysis technique utilized for this study. Merriam's (2009) standpoint is that all qualitative data analysis is inductive and comparative and subsequently draws heavily from the constant comparative method originally developed by Glaser and Strauss (1965) as a method for developing grounded theory. Coding was done according the inductive analysis method (Strauss \& Corbin, 1998). This method allows researchers to identify, create, and see relationships among parts of the data when constructing a theme. This method was utilized because it (a) builds theory, (b) provides tools for researchers to analyze data, (c) aids researchers in understanding multiple meanings from their data, and (d) provides researchers with a systematic process for analyzing data.

\section{Trustworthiness}

In qualitative research, the primary research instrument for data collection and interpretation is the researcher (Merriam, 2009; Patton, 2002; Pyett, 2003), which causes concerns with validity and reliability. Because qualitative researchers concentrate on discovering truth, credibility and reliability have been replaced with trustworthiness as Johnson (1997) suggests, it can be defended and creates a level of assurance in the findings (Golafshani, 2003; Lincoln \& Guba, 1985). To mitigate those concerns, a series of methods were used to strengthen the trustworthiness of this study that include: triangulation, peer debriefing, member checks, and the search for the negative case. Triangulation was achieved through the use of the interview data, analysis of media guides, interviewer notes, and analysis of the completed participant demographic questionnaires. Peer debriefing was achieved throughout the data collection process because the researcher acquired the assistance of peers to examine questions and review findings and supporting documentation in order to uncover any potential flaws, biases, or other shortcomings of this research that might detract from the credibility of this study. After each interview was conducted and transcribed, participants received a draft of their answers from the interview. The participants were allowed to clarify any remarks they felt did not adequately represent their ideas. Lastly, negative cases were sought out during the data collection process and explored to learn what factors contributed to student-athlete graduation.

\section{Results}

Stemming from the findings in this study, the researcher developed a conceptual framework to provide additional insight into the experiences of Black football athletes at State University. Eisenhardt (1989) and Baxter and Jack (2008) both established that qualitative case study research could lead to the development of theoretical frameworks that further enhance our understanding of the phenomenon. Therefore, Figure 2 depicts this conceptual model, which is introduced throughout the following sections incorporating findings and relying on data analysis to better understand the experiences of the participants. The model is divided into five phases: 


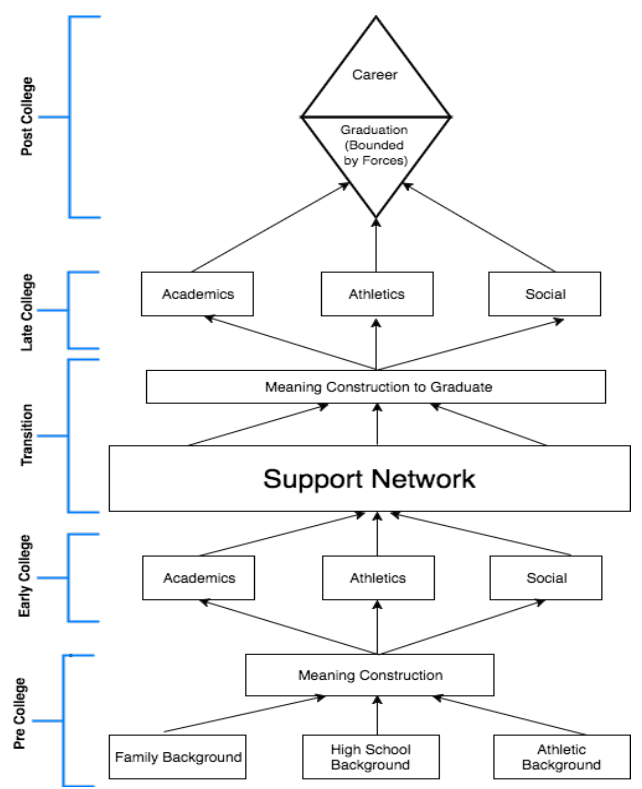

Figure 2. Model: Conceptual framework for football college athlete academic success

Table 4

Former Student-Athlete Family (FSA) Background Information

\begin{tabular}{|c|c|c|c|c|c|}
\hline & State & $\begin{array}{l}\text { Family } \\
\text { Income }\end{array}$ & $\begin{array}{c}\text { Family } \\
\text { Background }\end{array}$ & Community & $\begin{array}{l}1 \text { Gen. } \\
\text { College }\end{array}$ \\
\hline FSA 1 & $\mathrm{NC}$ & $25 \mathrm{~K}-35 \mathrm{~K}$ & Single Mom & Small City & $\mathrm{Y}$ \\
\hline FSA 2 & $\mathrm{OH}$ & $100 \mathrm{~K}-200 \mathrm{~K}$ & Two-Parent & Small City & $\mathrm{N}$ \\
\hline FSA 3 & MI & $50 \mathrm{~K}-75 \mathrm{~K}$ & $\begin{array}{l}\text { Divorced } \\
\text { Parents }\end{array}$ & Suburb & $\mathrm{Y}$ \\
\hline FSA 4 & $\mathrm{OH}$ & $50 \mathrm{~K}-75 \mathrm{~K}$ & Two-Parent & Small City & $\mathrm{Y}$ \\
\hline FSA 5 & IL & $25 \mathrm{~K}-35 \mathrm{~K}$ & Grandparent & $\begin{array}{c}\text { Large Urban } \\
\text { City }\end{array}$ & $\mathrm{Y}$ \\
\hline
\end{tabular}

Pre-College, Early College, Transition, Late College, and Post College. Each stage represents five distinct but intrinsically connected phases that capture the experiences of the former college athletes in this study. Following qualitative research methods, pertinent themes that emerged from data analysis that contributed to the creation of this model are presented and summarized in detail with rich participant accounts across each of the identified five phases. 


\section{Pre-College}

The pre-college phase denotes the experiences and background of the college athletes before beginning their collegiate career. Drawing from the findings of this study, the pre-college phase includes three components: family background (e.g., family socioeconomic status, family composition, and educational level), high school background (e.g., high school location, resources, diversity, and college academic background), athletic background (e.g., coaching experience, playing experience, and performance) and meaning construction components.

A key finding from this study is that not all Black football athletes originate from similar family or socioeconomic backgrounds. While it is true that many do come from single - parent households, this study reveals that other family compositions are also present. For example, FSA 5 was raised by his grandparents and discusses his family background by stating

[My] family upbringing was real rough. I grew up in a house with twelve, fourteen people in it...Mom wasn't around and my grandmother raised me...so [I come from] just a broken family...Dad [was] in and out but not consistently there. Growing up [I] didn't have much and had to learn how to survive from an early age.

FSA 1 presents a somewhat similar description regarding his family background by saying, "[I] grew up in a single - parent home [with] two older brothers...It was a tough neighborhood but I felt like that was typical for people of my ethnicity." These experiences reinforce the notion that many Black football players come from non-traditional, single - parent families and backgrounds that are not viewed as conducive for high educational attainment.

The single - parent and non-traditional family backgrounds are only one part of the story however. At least two of the participants came from a traditional two-parent household and another came from a family in which both parents were divorced and remarried. In speaking about his family background, FSA 2 mentioned, "We were middle-class in a middle-class economy. Probably income was $\$ 130,000$ between the two parents. We weren't wealthy by any stretch of the imagination, but we didn't really struggle for a whole lot and had a pretty comfortable upbringing." Even though FSA 2 came from a traditional two-parent household, he wanted to "get out of his environment...[because] nothing positive happened [where I'm from]." FSA 2 also stated, "Listen, I didn't come from a broken household...like both my father and mother were in my life...it was just that I didn't want to stay in [my hometown]."Even though the family backgrounds of the participants varied, each of them discussed wanting to get beyond their hometowns and achieve a greater level of success than the underachievement, which was the norm in their communities.

Not all the participants attended a high school in their home district. Some went to schools outside their district or attended a private school before transferring. For example, FSA 3 began his scholastic career at an all-boys private school and transferred to another private school before finishing his scholastic education at a high 
school in his hometown. The reason he eventually left the private schools was, as he stated, "I got tired of [the private schools] because they really weren't a good fit for me." When asked to elaborate on the reasoning why he felt that the private schools were no longer a good fit for him, he responded, "I just got tired of going to an allWhite boy's private school...I didn't fit in there."

The data revealed that the athletic background played a major role in the pre-college phase for college athletes, considering the amount of time and significance they attributed to playing football. FSA 2 clearly pointed out that "the goal in high school was to put yourself in the best position to earn a college [football] scholarship. Period. For me, that's why I put the amount of time I did in playing football." The academic rigor for most of the participants was not overly challenging and many of the choices made (e.g., high schools attended, time spent playing football, and classes taken) were driven by the possibility of earning a scholarship to play college football. Therefore, the participants dedicated a significant amount of time to participate in football - related activities (e.g., weight lifting, physical conditioning, film study, and practice) as compared to their academic pursuits.

Meaning construction denotes how individuals view and make sense of their world. This concept was developed by the social constructivist theory that understands the mind as an instrument that seeks to comprehend an objective knowledge, thus filtering input from the world in order to interpret the environment (Jonassen et al., 1995; Leahey \& Harris, 1985). It is important to note how the participants constructed meaning during the pre-college phase because that was the lens used to interpret their college experience, especially early on.

\section{Early College}

Based on the findings of this research, the early college phase as the next logical step because it encompasses the first two years on campus for the college athletes. The participants spent time trying to adapt to their new environment and responsibilities, which consists of three main parts: academics, athletics and social.

One of the key findings regarding academics, results indicated that participant's interactions with faculty members fell into one of three distinct categories: (a) faculty that were advocates/fans of athletics, (b) faculty that essentially did not care about athletics, or (c) faculty members that despised athletics. FSA 5 captured his interaction with faculty members in the following manner:

When you're black, first of all you know you're probably going to be an athlete. It's a high chance because you're Black at [State University], the numbers don't lie. One out of two [black male students], one out of three [black male students] are going to be athletes...there's going to be professors that don't like you because of that, because they don't feel like you were qualified in order to get into school, it was just your athletic prowess and then there are other professors that are football fans that want to see you succeed and will do anything for you [within the rules to help] because they know [or assume] that you're unprepared but they want to see you overcome. 
A significant athletic challenge the participants in this study encountered when they first arrived on campus was balancing their academic course work and athletic requirements. Spending over 40 hours weekly on sport related activities, while trying to adjust to the academic expectations proved to be a major challenge for the participants, especially during this phase of their college experience. FSA 3 stated, "When I first arrived at [SU] I felt that the academic work was something that I could manage but the real challenge was budgeting my time and teaching myself how to study." FSA 1 articulated it best when he stated, "I think I was prepared for the level of academics that State University was going to present me with. I wasn't necessarily prepared for the load and the time management that was required to handle the load."

With regards to the social aspect of the early college phase, one of the more significant emerging themes was that the environment initially proved to be hostile and unwelcoming for the participants as supported in the literature (Davis, 1994; Simiyu, 2012; Singer, 2005). FSA 2 captured this experience the best:

Many of [the students at State University] thought [we] were stupid...that's just plain and simple. And sometimes [the students] would talk to [me] in particular, like I was stupid and like [I] needed all the help that I could get...I felt like certain students thought that ...like I basically wasn't qualified [to attend State University].

Some of the animosity that FSA 3 experienced from his student peers in the context of their academic interactions centered on the fact that he was receiving a full scholarship to an institution that he was, in the students' minds, not qualified to attend.

\section{Transition Phase}

Between the early and late college phases lies the transition phase, which typically occurs between the end of the sophomore academic year and the beginning of the junior academic year. During the transition phase the participants interacted with and developed a network of people to aid in their adjustment to the college environment. These interactions with the support network ultimately helped to influence and refocus the meaning construction to graduate for the participants. The data revealed that the participants began to use their support networks to help find balance and manage the variety of stressors they encounter. FSA 4 initially established his support network because he was homesick when he first arrived on campus. He stated, "I'd just go into [the assistant athletic director's office] and just talk. I was home. I felt like being away from home, I was at home because I could talk to [them] about anything." Participants undeniably needed this support throughout their college careers when dealing with on and off the field challenges.

After college athletes have spent approximately two academic years on campus, interacted with faculty and staff members, been exposed to his football responsibilities, and has established their support networks, their sense of meaning becomes more refined and focused. The addition of meaning construction in the football athlete success model is a unique aspect because it explores how the football players 
interpret their environment. For some participants, being the first in their families to graduate from college was a significant milestone. FSA 2 mentioned that he did not want to be one of those former football players that went back to their hometown without having graduated from college. He mentioned:

What scares me the most and still scares me to this day is, you go back to [my hometown] and they're like, 'Oh, what's up? What you doing these days?' I'm like, 'Oh I'm back in [my hometown], and I'm not doing anything.' I did not want to go back to [my hometown] at all. Still don't to this day. Didn't want to go back to 'Damn you played for 4 years and you didn't graduate? What the hell did you do up there?' I think that scared me to death. I didn't want to do that.

This meaning construction is important because this is when they realize that graduation is not only a possibility, but a reality and a necessity.

\section{Late College}

Encountering the support network further helps to refine and establish how the participants interpreted the world around them. This refinement was critical for helping the college athletes manage their social, academic and athletic experiences more effectively at the late college phase compared to the early college phase.

As the participants were able to take control of their academic responsibilities once they had a better understanding of their environment and academic requirements. The participants in this study discussed were better equipped to handle their academic responsibilities because: (a) they passed the first two years of prerequisite courses and were able to choose a path that more closely aligned with their interest and, (b) knew how to handle their football and academic schedules. FSA 3, who mentioned that things began to "click" for him as he was able to get beyond his core courses, also noted, "after I was in college for a couple years, [I] realized how to do the work the professors wanted [me] to do...it really wasn't that hard." FSA 3 alluded to his development as he concluded by saying, "I easily got better grades during my junior and senior year...it wasn't even close." Participants were better able to manage their relationships with faculty members and create a more conducive learning environment at this stage. FSA 1 specifically mentioned that he did not seek out higher-level faculty members, "but just lower level faculty members that I could just go and talk to and get some good interesting insights... That only came after I felt comfortable with football."

One factor that guided the development of participants' time management was learning from older teammates. When asked how they learned to manage their time during the late college phase, FSA 3 mentioned, "I learned by experience... and watching some of the older guys...they really showed [me] how much time [I] really had." When dealing with faculty members, the participants indicated that they were able to find, interact with, and develop relationships with faculty members that were willing to help and share perspectives. After having experienced both the hostile and welcoming environments at SU, the participants were able to adjust to these 
distinct types of environments in the late college phase. The participants began to venture away from their teammates and discovered peers that shared similar beliefs or interests.

\section{Post College}

Findings suggested that graduation and career selection were especially important components in the overall experiences. According to the findings, the football related obligations influenced both matriculation and academic schedules. Further, majors and career choices of these participants were directly and indirectly influenced by football because most of the participants recognized that they enjoyed football enough to integrate it into their career path. Although during the late college phase, the participants articulated experiences of being able to better manage their athletic and academic requirements, football was still an influential force. FSA 2 had one of the most profound comments regarding this topic. He stated:

As I think about it now...yeah my senior year I knew what I needed to do in the classroom and I wasn't stressin' about anything football related...but no matter how much [I] tried to get away from it...football controlled damn near everything... like if I wanted to get another major...could I really? I don't think so... well... as along as it didn't conflict with practice.

In a similar manner, FSA 3 commented, "Yeah, many of [my teammates and I graduated] but we still didn't have the [flexibility] that everyone else has... and it's like even when we graduate football was still there controlling everything."

Four of the five participants are currently engaged in careers that involve football despite concentrating on different majors. This was a new finding and was not related to any previous literature concerned with the experiences of college athletes. Although football is not an active part of FSA 1's current career, football was still used as a means to be introduced to and meet his current employer. Therefore, whether directly or indirectly, football played a role in the graduation and on the current career choices of all participants.

\section{Discussion}

The results from this research supports, in part Comeaux and Harrison's (2011) assertation that academic success depends on the college athletes' ability to integrate with the social and academic environment. However, the Comeaux and Harrison (2011) model only segments the college athlete experience into two parts: Social and Academic System. The present research found that the experience of college athletes can be segmented into different phases (e.g. early college, transition, and late college phases) and that athletics participation needs to be called out into its own category. Wolverton (2008) says that college football players spend over 40 hours per week on football related activities, which leaves little time for anything else. Therefore, the ability of these college athletes to manage their athletic participation and balance 
their academic requirements is vital to all other aspects of their experience on campus. How the college athletes interpreted and managed their academic, athletic, and social environments became more refined the longer they were involved in the intercollegiate athletics system as compared to when they entered college as freshmen, which serves to fill in the gaps of the Comeaux and Harrison (2011) model.

Muwonge's (2012) organizational framework helps to clearly see the differences in the technical functions of the academic and athletic entities present at State University (see Table 2). This framework also showcases one fundamental challenge; the system of intercollegiate athletics does not change from the early college to the late college phase. College athletes, although better equipped to handle environmental challenges at the late college phase, recognize that they are still part of the system and the inherent conflict between academic and athletic responsibilities remains. This research found that it was not the level of academic rigor that provided the most significant challenge for these college athletes; it was the volume from both the football and academic requirements they had to manage. The system of intercollegiate athletics does not change and it is the ability of the college athletes to adapt and maneuver through their conflicting responsibilities that will help them in their academic pursuits.

Referring back to the original research question: How did Black football athletes manage to graduate while being part of a Division 1 team at a research-intensive institution? This study reveals that the most important factor in their experience was the relationship and interactions with people who provided them with a non-academic social support to navigate the college environment. Carter-Francique, Hart, and Cheeks (2015) conceptualize social support in four distinct components: (a) appraisal support, (b) emotional support, (c) informational support, and (d) instrumental support. Participants undeniably needed and utilized this kind of social support throughout their time on campus. Regardless of who the participants selected to be part of their support network, it is clear that this network itself was paramount for the participants' overall wellbeing. The participants selected their social network based on who they believed could help them navigate the college systems and had their best interest in mind, which supports Bimper et al., (2012) and Carter-Francique et al., (2013) findings that suggest college athletes will seek individuals who they can trust and seek advice and support. The present research also supports Bimper et al., (2012) and Cooper and Hawkins' (2014) research which found that Black college athletes routinely report being treated differently, isolated, inferior, and unfairly judged by their faculty, campus peers, and even teammates. The football field seems to have been the only place where Black athletes were embraced, which continues to propagate what Hawkins (2010) describes as the plantation system. Because of their experience on campus, developing their social support network ended up being vital to their overall matriculation through graduation, which supports Carter-Francique et al. (2013) research.

Another key finding emerging from this research suggests that the meaning construction the college athletes developed during the pre-college phase is the lens that they initially interpreted and viewed their college experiences when they first arrived 
on campus. As the college athletes managed their conflicting roles and interacted with their environments, they soon began to figure out how to best navigate their college environment, which further helped them to refine their meaning construction to graduate. The present research identified that a higher level of meaning construction occurred later on the college experience of the college athletes, which helped them to realize the importance for obtaining a college degree.

The present findings support Beamon's (2008) study in that football influences the priorities of the college athletes, which inhibits their ability to reap the full benefits (e.g. ability to engage in more campus events, internships, and travel abroad programs) associated with being a college student. Beamon (2008) further establishes that the reason football exerts a significant level of control over the lives of their athletes is two-fold. First, participating in football helped the athletes gain acceptance into the institution and second, football provided the financial assistance necessary for them to pay for school. The level of influence football exercises and the unique pressure on coaches to produce winning teams (Navarro \& Malvaso, 2016) creates an environment where football dictates the majors and how most of their time is spent during college, regardless of the adaptability of the athletes.

The resiliency the participants demonstrated to navigate their obstacles and matriculate to graduation was another significant finding. When the participants arrived on campus, they believed that playing college football afforded them opportunities that simply were not available in their hometowns. These participants wanted to use college athletics as a mechanism to achieve more than they initially believed possible, which also supports Bimper et al., (2012) notion about academics being "viewed as a tool for liberation" (p. 124). It is important to note that four of the five participants were first - generation college students, which helped to solidify the importance of obtaining a college degree which confirms Sellers' (1992) findings that Black college athletes recognize the value of a college education and degree.

In addition, previous research has consistently established that athletes with a strong athletic identity are more unprepared to manage their career transition out of their sport (Tyrance et al., 2013). However, the experiences of the college athletes indicate that as they were working through their career transition when their playing careers ended, most still enjoyed football and found ways to be involved with it in their career. Navarro (2014) establishes that career construction is a dynamic process, which is not neatly defined, but is an evolutionary process that considers the life experiences of students. It is not unreasonable to consider that because these athletes spent a significant amount of time on football - related activities over the course of their college careers (Tyrance et al., 2013) that they might enjoy being involved with football after their playing days have concluded.

Several implications emerge from the present study. The research found that the conflict between the academic and athletic enterprises within the university system remains consistent and college athletes have to figure out how to navigate both systems. Higher education professionals working with this population should help college athletes create a time management plan once they arrive on campus. This plan should consist of class schedules and football related activities but also groups/ 
events that might be of interest. A time management plan is the first and simplest thing to do which helps ensure that the college athletics can manage their conflicting roles.

Findings from this study demonstrate that having a support network was pivotal for college athletes and therefore higher education professionals should not only encourage college athletes to develop a support network of people they can trust but create a forum for the athlete to do so. Not only encouraging the college athletes to meet with faculty members but encouraging them to meet other staff members on-campus that share similar interest, could prove extremely valuable for the athletes. College athletic departments should also create a mandatory mentorship program for the first year and transfer students with mentors and faculty that understand their challenges.

The influence and impact of the coaches cannot be understated. Beside teammates, college athletes spend a large majority of their time with the coaches. Considering the time spent and a large majority of college football coaches are White, higher education professionals should require annual bias and cultural competency training for these coaches and staff. Another recommendation is to implement assessments and training to address mircoaggressions that faculty, staff, and coaches may exhibit when dealing with Black athletes. Training and assessments will be the best way to fully unearth the treatment of their Black players by the groups of people they encounter most often.

The lived experiences of college athletes demonstrate that many of them may want to pursue a career in athletics. College athletes have spent countless hours on their sports and subsequently may want to develop a career related to this industry. Therefore, athletic departments should consider creating programming or internships for these college athletes to gain some insight and experience working in different areas of the athletic departments.

Lastly, having introductory assessments for college athletes when they arrive on campus in the fall should be mandatory. These assessments should be tailored to: assess their interest, identity scale, goals at the university, importance of obtaining a degree, and family background. Each athlete brings their own baggage with them to campus and those working with them must understand this. Having this level of understanding will prove vital in understanding how the athletes construct meaning and better understand how to address their needs.

Exploring the experiences of college athletes both from revenue and non-revenue generating sports that did not graduate from their institutions or were delayed in their completion is the next logical step for future research. This research may be extremely useful in capturing a wide range of experiences that both positively and negatively impact their graduation. Future research should also seek to determine if injuries, lack of playing time, or an abundance of playing time effects their matriculation and persistence to degree completion. Lastly, Black female athletes are often excluded when discussing the experiences of Black athletes. This particular group of athletes has their own series of challenges that are vastly different than their male 
counterparts. It would be a disservice if researchers continued to discuss the experiences of Black athletes while leaving out those of the Black women.

Despite the variety of barriers imposed by intercollegiate athletics system, Black football players are provided with an opportunity to attend and graduate from a Division I research-intensive institution. This opportunity may not have been afforded to these individuals without their participation in athletics. The key factor in this opportunity is to ensure that these college athletes have a legitimate opportunity to reap the benefits of the education they were sold while being recruited by the coaches. Without providing a legitimate opportunity to reap the benefits of a world - class education, as Sellers (2000) says, the university would essentially be giving these college athletes a check that they cannot cash.

\section{References}

Astin, A. W. (1993). What matters in college? Four critical years revisited. San Francisco: Jossey-Bass.

Aud, S., Fox, M., \& Kewal-Ramani, A. (2010). Status and trends in the education of racial and ethnic groups. (No. NCES 2010-005). Washington, D.C.: U.S. Department of Education. Retrieved from http://nces.ed.gov.proxy.lib.umich.edu/ pubs2010/2010015.pdf

Azzam, A. M. (2008). Neglecting high achievers. Educational Leadership, 66, 9092.

Beamon, K. (2008). "Used goods": Former African American college student-athletes' perception of exploitation by Division I universities. The Journal of Negro Education, 77, 352-364.

Beamon, K. (2014). Racism and stereotyping on campus: Experiences of African American male student-athletes. The Journal of Negro Education, 83, 121-134.

Benson, K. (2000). Constructing academic inadequacy: African American athletes' stories of schooling. The Journal of Higher Education, 71, 223-246.

Berliner, D. (2013). Effects of inequality and poverty vs. teachers and schooling on America's youth. Teachers College Record, 115, 1-26.

Bimper, A., Harrison, L., \& Clark, L. (2012). Diamonds in the rough: Examining a case of successful Black male student athletes in college sport. Journal of Black Psychology, 39, 107-130. doi:10.1177/0095798412454676

Butler, P. (2012). Poor people lose: Gideon and the critique of rights. Yale Law Journal, 122, 2176-2204.

Carter-Francique, A., Hart, A., \& Cheeks, G. (2015). Examining the value of social capital and social support for Black student-athletes' academic success. Journal of African American Studies, 19, 157-177. doi:10.1007/s12111-015-9295-Z

Carter-Francique, A., Hart, A., \& Steward, A. (2013). Black college athletes' perceptions of academic success and the role of social support. Journal of Intercollegiate Sport, 6, 231-246.

Carson, E. A. (2014). Prisoners in 2013. (No. NCJ 247282). Washington D.C.: U.S. Department of Justice. 
Chen, S., Mason, N., Middleton, S., \& Salazar, W. (2013). An examination of behavioral data and testing scores as indicators of student-athletes' academic success. KAHPERD Journal, 51, 34-43.

Coakley, J. (2009). Sports in society: Issues and controversies McGraw-Hill Ryerson Higher Education.

Comeaux, E. (2008). Black male in the college classroom: A quantitative analysis of student athlete-faculty interactions. Challenge: A Journal of Research on African American Men, (1), 13.

Comeaux, E. (2012). Unmasking athlete microaggressions: Division I student-athletes' engagement with members of the campus community. Journal of Intercollegiate Sport, 5, 189-198.

Comeaux, E. (2013). Rethinking academic reform and encouraging organizational innovation: Implications for stakeholder management in college sports. Innovative Higher Education, 38, 281-293.

Comeaux, E., Bachman, T., Burton, R., \& Aliyeva, A. (2017). Undergraduate experiences of division I athlete science, technology, engineering, and mathematics (STEM) graduates. Journal of Science Education Technology, 26, 24-32. 10.1007/s10956-016-9648

Comeaux, E., \& Harrison, C. K. (2007). Faculty and male student athletes: Racial difference in the environmental predictors of academic achievement. Race Ethnicity and Education, 10, 199-214. doi:10.1080/13613320701330726

Comeaux, E., \& Harrison, C. K. (2011). A conceptual model of academic success for student-athletes. Educational Researcher, 40(5), 235-245. doi: $10.3102 / 0013189 X 11415260$

Cooper, J. (2012). Personal troubles and public issues: A sociological imagination of black athletes' experience at predominantly white institutions in the united states. Sociology Mind, 2, 261-271.

Cooper, J. (2016). Excellence beyond athletics: Best practices for enhancing black male student athletes' educational experiences and outcomes. Equity \& Excellence in Education, 49, 267-283.

Cooper, J., \& Cooper, J. (2015). "I'm running so you can be happy and I can keep my scholarship": A comparative study of Black male college athletes' experiences with role conflict. Journal of Intercollegiate Sport, 8, 131-152. 10.1123/ jis. 2014.0120

Cooper, J., \& Dougherty, S. (2015). Does race still matter?: A post bowl championship series (BCS) era examination of student athletes' experiences at a division I historically black College/University (HBCU) and predominantly white institution (PWI). Journal of Issues in Intercollegiate Athletics, 8, 74-101.

Cooper, J., \& Hawkins, B. (2014). The transfer effect: A critical race theory examination of black male transfer student athletes' experiences. Journal of Intercollegiate Sport, 7, 80-104.

Dancy, T. E. (2014). (Un) doing hegemony in education: Disrupting school-to-prison pipelines for black males. Equity \& Excellence in Education, 47, 475-493. 
Darensbourg, A., Perez, E., \& Blake, J. (2010). Overrepresentation of African American males in exclusionary discipline: The role of school-based mental health professionals in dismantling the school to prison pipeline. Journal of African American Males in Education, 1, 196-211.

Davis, T. (1994). The myth of the superspade: The persistence of racism in college athletics. Fordham Urban Law Journal, 22, 615-698.

Donnor, J. (2005). Towards an interest-convergence in the education of African American football student athletes in major college sports. Race, 8, 45-67. doi:10.1080/1361332052000340999

Ford, D. (2014). Segregation and the underrepresentation of Black and Hispanics in gifted education: Social inequality and deficit paradigms. Roeper Review, 36, 143-154.

Gatmen, E. (2011). Academic exploitation: The adverse impact of college athletics on the educational success of minority student-athletes. Seattle Journal of Social Science, 10, 509-583.

Glaser, B. G., \& Strauss, A. L. (1965). Awareness of dying. Chicago, IL: Aldine Atherton.

Golafshani, N. (2003). Understanding reliability and validity in qualitative research. The Qualitative Report, 8, 597-607.

Gragg, D. \& Flowers, R. (2014). Factors that positively affect academic performance of African American football student athletes. Journal for the Study of Sports and Athletes in Education, 8, 77-98. doi:10.1179/193573914Z.00000000020

Grandy, J., Lough, N., \& Miller, C. (2016). Improving student-athlete academic success: Evaluation of learning support tools utilized by academic advisors for athletics. Journal for the Study of Sports and Athletes in Education, 10, 199-217.

Harper, S. (2006). Black male students at public flagship universities in the U.S. status, trends, and implications for policy and practice. Washington, D.C.: The Joint Center Health Policy Institute.

Harper, S. (2009). Niggers no more: A critical race counternarrative on Black male student achievement at predominantly white colleges and universities. International Journal of Qualitative Studies in Education, 22

Harper, S. (2012). Black male student success in higher education. Philadelphia: University of Pennsylvania, Center for the Study of Race and Equity in Education.

Harper, S., Williams, C., \& Blackman, H. (2012). Black male student-athletes and racial inequities in NCAA Division I college sports. Philadelphia, PA: University of Pennsylvania, Center for the Study of Race and Equity in Education.

Harris, A. (2010). The economic and educational state of Black Americans in the 21st century: Should we be optimistic or concerned. The Review of Black Political Economy, 37, 241-252. doi:10.1007/s12114-010-9065-s

Hawkins, B. (2010). Economic recession, college athletics, and issues of diversity and inclusion: When white America sneezes, Black America catches pneumonia. Journal of Intercollegiate Sport, 3, 96-100. 
Hayes, D., Cunningham, M., \& Courseault, J. (2006). Race related barriers for African American males pursuing higher education: Implications for psychology. Race, Gender \& Class, 13, 124-132.

Hope, E., Skoog, A., \& Jagers, R. (2015). 'It'll never be the white kids, it'll always be us": Black high school students' evolving critical analysis of racial discrimination and inequality in schools. Journal of Adolescent Research, 30, 83-112.

Hughes, C. (2013). Poverty and disability: Addressing the challenge of inequality. Career Development and Transition for Exceptional Individuals, 36, 37-42.

Jonassen, D., Davidson, M., Collins, C., Campbell, J., \& Haag, B. B. (1995). Constructivism and computer-mediated communication in distance education. The American Journal of Distance Education, 9(7), 26.

Jones, J., \& Schmitt, J. (2014). A college degree is no guarantee. Washington, D.C.: Center for Economic and Policy Research.

Leahey, T. H., \& Harris, R. J. (1985). Human learning. Englewood Cliffs, New Jersey: Prentice Hall.

Martin, B., Harrison, C. K., \& Bukstein, S. (2010). "It takes a village" for African American male scholar-athletes. Journal for the Study of Sports and Athletes in Education, 4, 277-295. 10.1179/ssa.2010.4.3.277

Masten, A., \& Powell, J. (2003). A resilience framework for research, policy, and practice. In S. S. Luthar (Ed.), Resilience and vulnerability: Adaptation in the context of childhood activities (pp. 1-25). New York: Cambridge University Press.

McCormick, R., \& McCormick, A. (2006). The myth of the student-athlete: The college athlete as employee. Washington Law Review Association, 81, 71-157.

Melendez, M. (2008). Black football players on a predominately white college campus: Psychology and emotional realities of the black college athlete experience. Journal of Black Psychology,34, 423-451. doi:10.1177/0095798408319874

Merriam, S. B. (2009). Qualitative case study research. Qualitative research: A guide to design and implementation, 39-54.

Muwonge, C. L. (2012). Theocratic governance and the divergent catholic cultural groups in the USA. Unpublished Doctoral Dissertation, Eastern Michigan University, Ypsilanti, MI.

National Collegiate Athletic Association. (2015). Sport Sponsorship, Participation and Demographics Search [Data file]. Retrieved from http://web1.ncaa.org/rgdSearch/exec/main

National Collegiate Athletic Association. (2014). Trends in graduation success rates and federal graduation rates at NCAA division I institutions. NCAA.

Navarro, K. M. (2014). A conceptual model of Division I student-athletes' career construction processes. College Student Affairs Journal, 32, 219-235.

Ogbu, J. (2004). Collective identity and the burden of "acting white" in black history, community, and education. The Urban Review, 36, 1-35.

Owens, D., Lacey, K., Rawls, G., \& Holbert-Quince, J. (2010). First generation African American male college students: Implications for career counselors. The Career Development Quarterly, 58, 291-300. 
Palmer, R., Davis, R., Moore, J., \& Hilton, A. (2010). A nation at risk: Increasing college participation and persistence among African American males to stimulate U.S. global competitiveness. Journal of African American Males in Education, 1, 105-124.

Patton, M. Q. (2002). Qualitative research \& evaluation methods. Thousand Oaks, MI: Sage Publications.

Perlmutter, D. (2003). Black athletes and white professors: A twilight zone of uncertainty. Chronicle of Higher Education, 50

Quillian, L., Pager, D., Hexel, O., \& Midtbøen. (2017). Meta-analysis of field experiments shows no change in racial discrimination in hiring over time. PNAS.

Reeves, A. (2014). Written in black \& white: Exploring confirmation bias in racialized perceptions of writing skills. Nextions.

Reynolds, L., Fisher, D., \& Cavil, J. K. (2012). Impact of demographic variables on African American student athletes' academic performance. Educational Foundations, 93-111.

Sailes, G. (1993). An investigation of campus stereotypes: The myth of Black athlete superiority and the dumb jock stereotype. Sociology of Sport Journal, 10, 88-97.

Sailes, G. (2010). The African American athlete: Social myths and stereotypes. In G. Sailes (Ed.), Modern sport and the African American athlete experience. (pp. 55-68). San Diego, CA: Cognella.

Salkind, N. (2008). In Salkind N. (Ed.), Encyclopedia of educational psychology. Thousand Oaks, CA: SAGE. doi:http://dx.doi.org.proxy.lib.umich. edu/10.4135/9781412963848

Sanders, J., \& Hildenbrand, K. (2010). Major concerns? A longitudinal analysis of student-athletes' academic majors in comparative perspective. Journal of Intercollegiate Sport, 3, 213-233.

Sellers, R. (1992). Racial difference in the predictors for academic achievement of student-athletes in division I revenue producing sports. Sociology of Sport Journal, 9, 48-59.

Sellers, R. (2000). African American student-athletes: Opportunity or exploitation? In D. Brooks, \& R. Althouse (Eds.), Racism in college athletics (2nd ed., pp. 133-154). Morgantown, WV: Fitness Information Technology.

Simiyu, W. (2012). Challenges of being a Black student-athlete on U.S. college campuses. Journal of Issues in Intercollegiate Athletics, 5, 40-63.

Simons, H. D., Bosworth, C., Fujita, S., \& Jensen, M. (2007). The athlete stigma in higher education. College Student Journal, 41, 251-273.

Singer, J. (2005). Understanding racism through the eyes of African American male student-athletes. Race Ethnicity and Education, 8, 365-386. doi: $10.1080 / 13613320500323963$

Singer, J. (2008). Benefits and detriments of African American male athletes' participation in a big-time college football program. International Review for the Sociology of Sport, 43, 399-498. doi:10.1177/1012690208099874

Smith, S. (2005). "Don't put my name of it": Social capital activation and job-finding assistance among Black urban poor. American Journal of Sociology, 111, 1-57. 
Strauss, A., \& Corbin, J. (1998). Basics of qualitative research (2nd ed.). Thousand Oaks, CA: Sage Publication.

The Sentencing Project. (2013). Report of the sentencing project to the united nations human rights committee: Regarding racial disparities in the united states criminal justice system. Washington, D.C.: The Sentencing Project.

Tyrance, S., Harris, H., \& Post, P. (2013). Predicting positive career planning attitudes among NCAA division I college student-athletes. Journal of Clinical Sport Psychology, 7, 22-40.

U.S. Department of Education Office for Civil Rights. (2014). Civil rights data collection: Data snapshot (school discipline). U.S. Department of Education. Retrieved from https://ocrdata.ed.gov/downloads/crdc-school-discipline-snapshot. pdf

Warikoo, N., Sinclair, S., Fei, J., \& Jacoby-Senghor, D. (2016). Examining racial bias in education: A new approach. Educational Researcher, 45, 508-514.

Whiting, G. (2009). Gifted black males: Understanding and decreasing barriers to achievement and identity. Roeper Review, 31, 214-233. doi: $10.1080 / 02783190903177598$

Wolverton, B. (2016, January, 5). Athletes' hours renew debate over college sports. The Chronicle of Higher Education. Retrieved January 5, 2016, from http:// chronicle.com 